\title{
Conflict and Cohesion in Mission Communities in Africa: An X-Ray
}

\author{
Nmah, Patrick \\ Enoch-Department of Religion and Human Relations, Nnamdi Azikiwe University, Awka-Nigeria \\ Email: patricknmah@yahoo.com
}

Udezo, Benson Okechukwu

Sunday-Department of Religion and Human Relations, Nnamdi Azikiwe University, Awka-Nigeria

Email: benson Udezo@gmail.com

\section{Doi:10.5901/mjss.2016.v7n2s1p35}

\begin{abstract}
This paper aims to reveal issues involved in the conflict and cohesion between the missionaries and African communities. The objective of this research work is to investigate the issues such as polygamy, African religious beliefs and practices involved in the conflict and cohesion in the course of missionary enterprise in Africa. The significance of this research work is that it shows the reasons why African religion and culture continue to thrive in spite of the onslaught on them by the missionaries. The findings showed that it is better to apply religious dialogue in dealing with the conflict. Since the theme deals with Church history and elements of African traditional beliefs and practices, that is why it is imperative to adopt primary and secondary sources in data collection.
\end{abstract}

Keywords: Mission, Conflict, Polygamy, Human sacrifice, Education

\section{Introduction}

Historically, conflict and cohesion in mission communities during the missionary enterprise in Africa depicts the attitudes of the missionary activity towards the basics to certain time-honoured institutions such as family land, polygamous economy, traditional religion, the magic world-view, divination and the like was deplorable (Nmah, 2010). The widespread missionary disparagement of tribal religion is a further case in point. The background causes advanced in the literature can be classified for convenience sake namely historical factors ( most case studies on conflict have been written from historical and descriptive points of view and causes are put forward in terms of the history of a people and the missions who worked among them, usually as local factors unique to the case being studied), political factors, issues bordering on polygyny, the earth-goddess, traditional African family, colonial factors, sociological factors (the colonial colour bar policy such as in South Africa, Zimbabwe, Kenya etc), hankering after ancestor-worship, native love of pomp and colour, missionary ignorance of African psychology, language, avarice, ambition, imperiousness, and faulty biblical interpretation.

Other causative factors include ethnic and theological factors as examined by Barrett (1970) and Ndiokwere (1995). The gospel was consequently ascribed the miraculous power that produced conversion, unity, and the missionaries unwittingly interpreted Christianity to mean the same thing as Western civilization. Their common interests, particularly their fears of African revolts, kept the missionaries, their converts, traders and colonial masters together. The importance of the eventful coming into Africa by the European Christian missionary remains very clear and of essence for the Africans great reawakening; and because we cannot fail or be tied to a common assumption that the encounter or relationship between the European missionaries and the African people were all rosy and smooth. There is no doubt that the missionaries that came to Africa to Christianize and civilize the African society had an ambivalent character in their quest to modernize Africa and also better their own economy. In this study therefore, the research is to be focused on a critical examination of the conflict and cohesion in mission communities in Africa. That is those elements of conflict that existed between the European Christian missionaries with the African society and the seemingly cohesion that were establish or re-established in the mission communities. 


\section{Research Objectives}

The objectives of the study include:

To investigate the causes of the conflict and the challenges posed by the conflict

To examine the basis of the cohesion that made Christianity to thrive in Africa

To create the awareness to the world about the encounter between Christianity and African culture

To investigate the various instruments of maintaining unity in the African Christian communities

To also examine the implications of the contemporary challenges towards the development of the church in Africa

\section{Significance of the Study}

The significance of this study basically stems from the fact that it addresses the issues that threatened the collective existence of Christian communities, and offers a valid and insightful resource material those future scholars especially church historians can consult to gain useful information on the conflict and cohesion in mission communities in Africa.

\section{Literature Review and Hypotheses}

\subsection{The emergence of Christian mission}

Christianity otherwise Christian religion is believed to have been founded in what is today known as Israel and Palestine for over 2000 years now. Christianity is a religion based on the life and teachings of Jesus Christ, a Jewish teacher and a prophet. The early Christians that were followers of Christ believed that Jesus was divine in that he was the son of God. And this has been a major difference between Christianity, and another two notable religions Judaism and Islam. History has it that Judaism does not believe that any of their great prophets were divine. Consequently, Christianity like Islam is seen as a proselytizing religion, meaning that followers of these religions believe it is their duty to share their religion and try to convert others to their religions.

This obviously informed the European exploring of un-evangelized areas of the African coast in other to bring the message of Christian religion to the people. From historical point of view, Falk (1997) was apt to observe that toward the end of the thirteenth century, Europe witnessed an awakening of a search for knowledge in religion, exploration, science, and industry. The invention of compass, the new knowledge and skill of navigation, and the large and stronger vessels therefore encouraged the people to venture to unknown regions. From 1364-1387 ten expeditions were sent to the coast of Sierra Leone. Franciscan missionaries sailed with the Portuguese expeditions to Madeira (1420), the Azores (1431) and the Cape Verde Islands (1450). Everywhere else along the West African coast, the Portuguese ruled and for the most part, the Roman Catholic mission dominated most part of black Africa during the fifteenth through the seventeenth centuries were under Portuguese auspices.

Cognizance is to be taken of the fact that both Dutch and British undertook their exploratory and commercial ventures together with the objective to plant its reformed faith in its territories of which the British thought otherwise. But a new and pervasive determination in the Protestantism to carry the gospel to all men was aroused in the eighteenth century evangelical revivals in England and America. In affirmation to this, Shelley (2008) observes that:

Only in the 1820s and 1830s did interest in overseas missions become a general feature of British Church life. This was due in part to the success of evangelical in influencing English and Scottish society. Many of their values were adopted outside their circle. In particular, the idea of Britain as Christian nation, with Christian responsibilities overseas took root (p.377).

Following the decision of the Protestant churches to integrate the need and the passion to preach the gospel to the un-evangelized people of the world and Africa; this promptly made them to establish a Christian mission with the sending of some Europeans such as Dr. David Livingstone, a medical doctor, on a routine of missionary work in Africa. This was actually followed by an influx of European missionaries into the coast of Africa for the purpose of mission work, which entails evangelism in mission communities of Africa. There is no doubt the fact that the gathering of these mission communities was without its problems and envisaged kinds of conflicts. 


\subsection{Factors involved in the conflict}

In defining the word conflict, Nmah (2008) was of the view that "conflict is a process that begins when one person sees that another person has damaged or is about to damage something that the other person cares about" (p.179). A further insight from Nmah shows that there are about four types of conflicts, functional conflict, dysfunctional conflicts, and person versus group conflict. Functional conflicts are constructive conflicts, dysfunctional conflicts are destructive conflicts. A person versus person conflict involves two people who are at odds over personality differences, values conflicts, loyalties. Person versus group conflict occurs most often when a member of a group breaks its rules, or norm.

It cannot be overemphasized that the missionaries that came to Africa had a very lofty ideas guided with sympathy and humanitarian stand point as a concern for the ordeal of Africans in the hands of slavery. And therefore emerged not only to an outlaw slavery and slave trade in line with Christianizing the people, but as well as to offer them civilization and genuine form of trading activities. With these facts and realities notwithstanding concerning the undoing of the missionaries, there are some discrepancies that hitherto existed between the missionaries and the mission communities, the people they came to evangelized with the good news regarding Christ. As a matter of fact these discrepancies formed out right the backdrops of the conflict that existed in the mission communities. To this end, the missionaries' ambivalent character toward African beliefs and practices certainly became a huge issue. From Babalola's (1988) statement "they launched assaults upon customs and beliefs which they found objectionable and thereby caused conflict and alienated the majority of the people they had come to convert" (p.15). At this point, some of these areas of conflicts and cohesions in mission communities can be enumerated as follows.

\subsubsection{Colour-bar missionary approach}

In South Africa, for instance, apartheid or separate development was the ideology that was hoped would guarantee the survival of the Boers as a nation. To Baur (2005), they had been defeated by British imperialism (Boer War 1898-1902) and they were in 1910 forced into the Union of South Africa, in which they feared they would be submerged by the evergrowing African race. The industrial revolution that transformed the country into an industrial state not only changed the Boers, that is farmers, into urban dwellers-henceforth calling themselves Afrikaners. When after the World War II, the liberal government of General Jan Smuts envisaged the eventual opening of the Parliament to all races, the whites voted into power the National Party of Dr. Malan and Dr. Verwoerd (1948). They in turn inaugurated "the struggle for racial purity" (the Nazi ideology), coupled with the war against "godless communism" (the devil at the wall) in the name of "Christian Civilization" (the religious sanction).

The Great Trek led them to a further identification-Like Israel of old they had experience a great exodus from British oppression into a land of freedom and prosperity. Hitherto they too were God's chosen people entitled to take possession of the land into which they were led. In their covenant of the Trek they promised not to attack, only to defend themselves, but in practice they had to subdue all the neighbouring Africans who regarded them as aggressors. To subdue them meant to make them their servants. For this the story of the Gibeonites provided the classical precedent: Joshua spared their lives but made them "hewers of wood and drawers of water" (Jos. 9:27). This way the social structure of the white masters and black servants was once more sanctioned by sacred history.

To Baur (2005), the Catholic bishops admitted the problem already in their 1957 pastoral, saying "we are hypocrites if we condemn apartheid in South African society and condone it in our own institutions." Unfortunately, this hypocrisy was to stay on in all the churches, Catholics as well as Protestants, in spite of Archbishop Denis Hurley's and other critics' constant calls to overcome it. The African reaction proceeded precisely from this practical discrimination in the churches, which of course had existed long before the official apartheid policy. For in the black daughter churches as well as in the multiracial churches the Africans felt dominated by either the missionaries or by the white members and tensions appeared time and again. The earliest and most radical, black reaction had been the founding of independent churches, in which alone the African leadership ability could freely develop. The myriads of splinter groups are precisely the reflection of a desire for power and prestige which is not achievable elsewhere and their great success is proof of the African need for a self-expression, denied in the mission churches. The indigenous churches symbolize the black revolt against European spiritual and cultural domination" (De Gruchy, 1979, p. 47). Nevertheless, over all the years of trials, there emerged something like a black church- a black Christian solidarity, pervading all denominations and trusting in the gospel of Christ as the liberating power of God for black and white alike. De Gruchy (1979) concludes, "At the center of the church struggle throughout South African history is the struggle of the black church to prove to its fellow blacks that Christianity is not the 'opiate for the people' but the hope of the future" (p. 51).

In the growing conflict, in the 1950s, there was still hope that the apartheid government would be a passing cloud. 
The most prophetic voice of the time was the Anglo-Catholic priest Trevor Huddleston. His first alarming article was entitled, "The Church sleeps" with the explanation "but worse, sometimes it talks during the sleep" (Huddleston, 1957). The DRC considered the baptism of children of Christian parents proper because they are already in the covenant. But the baptism of the children of unbelievers was considered unlawful (Falk, 1997). George Schmidt who made some converts among the Hottentots was not allowed to baptize them. When he eventually did baptized six persons in nearby streams, he was called before the governor, the council of policy, and the clergy. He was forbidden to administer the sacraments until the Classis of Amsterdam would clarify the matter. Schmidt returned to Europe and the Dutch Reformed Church requested that Schmidt serve under its auspices. He therefore stayed in Europe and served as a pastor in a Moravian settlement. The Hottentots waited for his return until they received the sad news of his death in 1785 .

The mission in the Cape ceased for nearly fifty years before the Moravian Church reopened Genadendal. Several pastors of the Dutch Reformed Church did much to arouse the conscience of their white congregations. The first one, Van Lier, while a minister at Cape Town from 1786 to 1793, repeatedly presented the necessity of missionary work among the Hottentots and encouraged the church in Holland to organize a missionary society. The Anglican Church had not taken root in the country during this period. When the Anglican pastors, who came as chaplains with the army, baptized either Hottentots or slaves, the authorities of the Dutch Reformed Church protested (Hinchliff, 1968). At the beginning of the nineteenth century, the London Missionary Society (a non denominational Christian group responded to the challenge to evangelize the people of South Africa. Other missionary bodies that entered South Africa include the Glasgow Missionary Society, Wesleyan Methodists, Presbyterians, Congregational, and among others.

To Baur (2005), another basic tenet of conflict was the Augustinian view of history as a fight between the kingdom of God and the kingdom of Satan. Hence missionaries saw the fight against paganism as a fight against Satan, and traditional religion simply as idolatry. Its sacrifices were "adoration of Satan", to be fought as Satan himself. This was due to two misconceptions: on the one hand, there was the unfortunate but suite general European prejudice that Africans were a primitive people without religion; on the other hand it had become generally accepted in Europe that all magic and all spirits were devilish. That was the missionary method of the Capuchins. Consequently the missionaries, not knowing anything about ancestor and fertility and cults, or the African distinction between protective and harmful magic and between medicine man and witch, rejected all and everything as Satan's service. Hence all fetishes had to be burnt or buried. As a consequence the medicine men became their great adversaries, to be pursued mercilessly until they submitted. This ruthless attempt at rooting out all superstitions can only be explained by another European axiom: "There is no pact with the devil".

Prior to the advent of the missionaries, possession by evil spirits, diseases, sterility, fear of witchcraft, mental disturbances caused by insecurity and difficult socio-professional relations, badly affected people who in this new environment are constantly looking for a brother or leader who speaks the same language and can bring comfort and support in difficulties. The traditional African religions, which are based mainly on ancestral beliefs and practices and are supported by strange tribal solidarity, gave to individuals and groups a certain overall equilibrium and social and contextual integration (Gifford, 1993).

Once again a common European prejudice, this time a misinterpretation of the Bible, hindered any deeper understanding of the African social situation. Africans were regarded as the "cursed sons of Ham", hence polygamy, and also trial marriage were understood as symptoms of their unbridled sensuality. Canon Law had to be strictly observed; customary marriage was to be regarded as concubinage. The fear of eternal damnation must have been the main motive for complying with the two basic religious demands; to give up superstition and polygamy. The Capuchins saw to it that concubines found other partners and that the wedding feasts were celebrated with great pomp. The Christian couples were highly honoured and their children praised as "children of grace." Between 1673 and 1701, some 50,085 marriages were celebrated in the whole country-a figure not reaching by many modern dioceses of the same size.

At the very arrival of the first missionaries the Mani Soyo gathered Nkisi (fetishes) to be burned by the Christian priests. He thus followed the well-known African pattern of destroying old fetishes to make room for a new, more powerful one. Baptism, crosses, statues, church ornaments, were seen as the new "nkisi," and the Christian priests as their "Nganga." The witch-doctors of Nkadi Mpemba especially feared the Capuchins and their power: they and their followers would always flee at the sight of even a single Capuchin, accompanied by a few pupils.

The greatest problem that Christianity encountered in the kongo just like most of the African continent was how to deal with the most inept and deepest-rooted religious cult, the veneration of the water and earth spirits, associated with fertility. The dominant symbol of this cult was a giant snake, living in waters, and jumping on trees; it was called Mbumba, "the Fertile." The veneration was complex; it centered chiefly on trees; the spirits were believed to give health and fertility and prevent death and sterility. Among the ministers the most important were the Kitome, the owners and lords of the land; their position was the most sacred. They regulated the whole agricultural life, produced rain, blessed the seeds, 
permitted the harvest and received the first fruits.

In the words of Okeke (2006),

Undoubtedly, the Igbo people of Nigeria considered the remarks made and action taken against their system of marriage with a critical intent. Monogamy was presented to them as God's decreed demand for all races. But right before their eyes were examples of a doubt standard morality with concubines or mistresses (p.139).

The conflict that existed here as a matter of fact just as Okeke rightly pointed out was that the missionaries were totally against polygamy, but right before their eyes they were seen having concubines and mistresses. Of course Africans may have wondered whether any difference exists between the both. But as a matter of fact blames should therefore go to Bishop Crowther who seems to be too English in certain issues as pointed out by Ayandele in Nnaemeka (2007) stating that Crowther made a sentimental pronouncement on polygamy and thus misled the Lambent Conference of 1887 on the real position of polygamy in Africa. He saw polygamy as a form of slavery for women.

Ekechi (1972) remarks also that it should be pointed out, however, that the double standard of some of the Europeans and other coast traders (including African leaders), who professed to be Christians, provided added incentive to return to the traditional life. From the 1860s and more so in the 1870s many merchants at Onitsha, white and black, retained mistresses in their houses. To most people their actions constituted a blatant inconsistency with their espousal of the Christian teaching on monogamy. It was difficult for the indigenous people to reconcile the practices of the white men with the teachings of the missionaries.

Again, at Umunya, Perry preached the gospel of peace, pointing out to the people the futility of war. The people listened with critical evaluation. Perry reported how they remonstrated him:

They said that if my mission was in reality to preach peace, would it not be better for us (the agents of civilization) to refrain from selling guns and powder and knives? For we brought these things (Okeke, 2006, p.144).

At Nri, its elders began a religious argument with Perry. They tried to demonstrate their superiority over all the Igbo, even the world beyond:

They were as it were, the Levites of the Igbo people, who dwell in these parts; in fact their influence extends to Igala and near Idah. They consecrate or crown the Attah of Igala, and the kings or chiefs this way are crowned or consecrated by them. Whatever they say that is wrong is wrong, and whatever they say is right is right. Infants and grown up people who are to be sold because of some social or political crime or what might be regarded as such, are given to them (Okeke, 2006, p.145).

But with persuasions the missionaries were able to perhaps to an extent convert Africans into living a Christian life as expected of the missionaries of marrying one wife (monogamy). The truth is that Africa by and large still remains a continent of polygamy with a visible and appreciable cohesion.

The missionaries attack on the African customary pattern of marriage, in which the emphasis from the missionaries was for Christians to show a radical attitude of disdain toward traditional pattern of behaviours against African system of marriage in Igboland was very clear. As rightly pointed out in Okeke (2006):

Two measures were adopted by the C.M.S in their attempt to regularize in Igboland what is generally regarded as a Christian marriage. The first was the approach of Bishop Crowther and his fellow workers. Secondly, the futile attempt by Bishop Tugwell to enforce ordinance marriage alone without Igbo traditional form of marriage (pp.139-140).

As a result, many of the Africans disliked the attitude of the agents over polygyny. It is understandable that the missionaries, however, regarded Africans (Igbo) patterns of life as being absolutely embedded in idolatry. In a further insight Okeke led us to understand that African agents of the mission, however, argued that the English system of marriage, as embodied in the prayer book, was quite at variance with the African traditional view of marriage and inheritance. Particularly, the pledge given in the marriage ceremony in England was considered irrelevant for the African, where communal ownership of property prevailed.

This in essence clearly speaks volume of the fact that the Christian missionaries actually failed to take into consideration on their arrival in Africa that the religion which they intended to introduce to Africans was culturally different from that which the established religion of the Africans had developed on. Ekechi (1972) was of the view that:

The almost wholesale condemnation of indigenous customs by Europeans at times disturbed many of the Igbo 
evangelists. As a conference of CSM missionaries held at Onitsha on 12th May 1914, several of the customs were discussed. The few Igbo representatives at the conference argued eloquently in favour of allowing some of the customs. They impressed upon their European colleagues that a realistic approach to local beliefs and practices was necessary if Christianity was not to mean social disintegration (p.165).

However cohesion was arrived at according to Okeke's (2006) vivid observations that it was the Igbo Christians themselves who created measures most suited to their environment.

The act of human sacrifice in Africa had been an aged long obnoxious and hideous religious ritual prior to the coming of European missionaries with Christianity into Africa. It was therefore a welcomed idea that the missionaries totally condemned and endeavoured to put a stop to the nefarious act of human sacrifice for whatever reason or purpose. Though it generated lots of conflict between African rulers and the missionaries, but the action of the European missionaries on the issue was perceived by the people as an act intended to sanitize the society from cruelty and it died a natural death.

But with the turn of events and the missionaries' sudden involvement in slave trade even when the act had been outlawed with some persons described as imposters of the government officials seized people over taxations and would latter sold them into slavery. According to Ekechi (1972) "If the victims were Christians, however, the chances were that they could not be sold. For according to the missionaries, a Christian was no longer subject to sale as a slave" (p.149). As a matter of fact it created a chaotic social upheaval in the environment to an extent that safety and security appeared to have been tied to belonging to a Christian religion. And so as to avoid being taken into slavery people rushed into accepting Christian faith. But apart from the tension and conflict this act of the missionaries' involvement in secret slave trade business generated, it may not be far from the truth that those slaves were eventually used as an object of human sacrifice by those who bought them.

These actions of the missionaries certainly prompted the bewilderment of most Africans as captured in Nnaemeka (2007) berating the fact that since the missionaries who were preaching Christ and the love of one's neighbour also involved themselves secretly in slave trade, it was difficult for Africans to reconcile the preaching of the missionaries with their actions. It is therefore imperative to note that these actions of the missionaries really masterminded serious conflict in mission communities of Africa. But with serious disciplinary measure on the culprits from the colonial government cohesion was restored to the mission communities.

Following the European missionary advent in West Africa they may have thought of tackling slavery and slave trade issue as the only menace that stands to be confronted and eliminated. But unknown to them that there exists some obnoxious and heinous religious practices of the African society that sees the birth of twins as an anathema and an aberration whose ultimate end should be elimination of their life. As an opposition and challenge that stirred the church (missionaries) on the face, just as Nnaemeka (2007) emphasize "that the church fought against various ills, like the killing of twins and human sacrifices (p.21).

The missionary fought and struggled to stop and eliminate the killing of twins was a fight to finish with a strong resistance as put forth by most Africans against the laudable objective of the Christian missionaries. Taking the event as it unfolds in Onitsha the eastern part of Nigeria, Okeke (2006) observes that:

The 1877 trouble was sparked off by the determination of the converts to save the twins of Daniel Odiegwu. Over 300 able bodied men trooped into the home of the converts, killing a few and ravaging their property, as well as the property of the foreigners. Two leading converts John Iweobi and Edward Emejuru were martyred while trying to defend the twins and to justify the godly intention to preserve life. Throughout the struggle, Simon Jonas Mbanugo counselled the converts not to react with force. The twins were saved and handed over to Archdeacon Crowther who was visiting Onitsha at that time (p.148).

True to it that the Christian missionaries from the time of a Scottish woman named Mary Slessor who lived in Calabar Nigeria had been credited to have stopped the killing of twins in Africa. But the crisis that precipitated its stopped notwithstanding, it can be said that they were some elements of cohesion that played out which ensured it permanent seal. As Okeke further gave an insight that it was Mbanugo who helped to foster closer relationship between the non converts and their Christian brethren. Through his initiative, a peace panel was instituted for the amicable settlement of such matters as twins' trouble.

\subsubsection{Education}

Among the strategies adopted by the Christian missionaries as an instrument of conversion in Africa was the introduction 
of western education. Omoyajowo (nd) accounted to the fact also that when the missionaries arrived in Africa, they preached the gospel and in addition taught their converts how to read and write. They employed the only method known to them, that of western education and culture. It is of note that from the beginning, education was of prime importance in evangelism and every mission station had its own school. In Sierra Leone the CMS in 1845 opened a grammar school in Freetown to give secondary education to boys not only from the colony, but also other parts of the coast. The same is to be said of Nigeria where the missionaries centered the mission stations on schools.

But the questions that ever agitated the minds of the Africans had always be the usefulness of this missionaries system of education to their well-being. According to Falk (1997),

The different purposes for education held by the churches and the people frequently caused much confusion. The church leaders were basically concerned with training personnel for the ministries of the church, whereas the church members expected the church schools to provide their children with the best tools for a good livelihood (p.436).

\title{
Ekechi (1972) further pointed out that:
}

\begin{abstract}
As men were considered the natural heirs to the father's estate, the parents preferred the occupational education which the children received at home. Such education, it was thought, was more important than the formal schooling introduced by the missionaries. To the African parents and their sons, agricultural work was preferable to mission education. There is no doubt that Taylor and his fellow missionaries imbued with the notion that British or European-oriented education was superior to the indigenous system of education, failed to appreciate this (p.24).
\end{abstract}

From every true sense of it all, it is an appreciable reality that early Christian missionary faulted in their neglect of the African system of education which was hinged on self-reliance, self-sustenance and self-propagating. And for the European missionaries to have labeled the desire of the Africans for a skill oriented type of education of theirs as an uncivilized greatly exposed the imposition of western education and culture to extinct that of Africans.

To this end, the conflict of western education to the African culture could be further traced to an attempt by the missionaries to extinct the laudable custom of good African behaviour in young ones act of kneeling or bowing before the elders, which was seen and interpreted by the missionaries as a mortification. Ekechi (1972) remarks that it is clear from the records and from the actions of the converts that the kind of Christianity which was introduced into the country tended to make the Christians profoundly un-African and uprooted from their culture. The Christian church and the school became, in essence, the most important mechanism for detaching the young from their tribe they have been brought up. Basically, the issue to be grasp from Ekechi's postulations remains that western education from the eyes of the African people caused damages to the behaviour and the conducts of their children.

However, cohesion could be said to have been attained in the mission communities firstly in Sierra Leone with the establishment of African church and the total withdrawal of European missionaries due to African climate in 1861 and handing over the mission work in the hands of the Africans. But following the establishment of Sierra Leonean native church by 1850 as an African Diocese of Sierra Leone, Babalola (1988) observes that:

Sierra Leone evolved a system of education that lay emphasis on the production of the professionals. Thus the first African doctor, lawyer, newspaper editor and journalists were produced in Sierra Leone. In British colonies in West Africa, the Creoles from Sierra Leone serves as Supreme Court judges, colonial treasurers, solicitor General, post Master-General, the chief medical officer, chief justices, court Registrars, legislative and Executive council members in various West African countries (p.46).

Consequently, all other West African territories take a leaf from the Sierra Leonean system to establish African churches under the control of Africans. In what is known as itineration, a policy that was geared towards opening up new stations in most Niger mission of Nigeria. According to Okeke (2006):

Before the end of 1893, the effect of this itineration began to be felt. In 1894, three stations were opened and occupied by Igbo teachers. With the opening of these new stations, the staff strength was spread more thinly. Therefore, Dobinson planned for a regular training scheme in order to maintain a steady supply of teachers for the stations. Already Miss E.A Warner and her Lady assistants were doing a notable work among the Igbo girls. Instruction in sewing and domestic work had begun (p.271).

On a further insight Okeke was quick to point out that by February 1895, the Asaba Training Institute was formally started under the superintendence of Spencer and H. Meriman and other Sierra Leonean recruits. This is however all about giving Africans an education that are full of skill and professional oriented for a cohesive society. 
According to Anyacho (2003), "The introduction of formal education was the greatest and the most spectacular achievement of the missionaries. They regarded education as an instrument for evangelization and so promoted it right from the onset" (p.116). The promotion of education right from the onset by the missionaries actually began from the mission houses which gave it a starting point where it all got started and ensured a regular attendance of school by the converts or the boarders. The kind of cohesive education brought through the mission houses cannot be overemphasized.

It is of note that following Henry Venn's principle to train middle class Africans, especially the youths on a skill based education for self sustenance, self reliance and self propagation; this actually made him to gather resources from government, humanitarians and trade agents in other to affect the training of these African youths in various industrial skills. This therefore led to the formation of the Native Agency committee with the aim of improving the religious and social status of Africans by the means of their own sons. In this way they started sending these young Africans from the mission houses to England for the industrial training or another.

In fact they encouraged individual African merchants and mission agents to train their children for practical industrial education in England. Following this process many African youths left for London and were trained in tile and brick making skills, some in navigation and seamanship as well as some in medical fields. It is important to note that on their return from England the missionaries organized a kind of an apprenticeship workshop in the mission house whereby these England trained artisans passed on their skills of industrial trainings of various kinds to a large number of people in the mission house.

\subsubsection{Missionaries and socio-economic dispute in Igboland}

The revival of Christianity in Europe and America during the eighteenth century resulted in the formation of the society for the abolition of slave trade in Africa. And this actually informed the desire of the Europeans to trade with the people of the interior Africa with them advancing into West Africa also for a Christian missionary enterprise in Igboland. This is as a result of what Ekechi (1972) believes was "in response to the ideas of Thomas Fowell Buxton, the humanitarian, who claimed that the best way to stop slave trade and regenerate Africa was to establish legitimate commerce with the African rulers: by introducing commerce, civilization and Christianity"(p.1). These were the three fundamental principles of approach which the missionaries had in mind as they penetrated West Africa and Igboland in 1857.

In a further narration on the arrival of the missionaries in Igboland Okeke (2006) observes that "Under the leadership of Dr. William Baikie, the party arrived at Onitsha, Obi Akazua and his elders-in council, gave them a formal welcome" (p.23). As very much expected in their meeting with the king and chiefs of Onitsha their discussion was centered on the indigenes helping them to institutionalize Christianity and in return the C.M.S agents shall assist the traders by establishing a trading factory or company. The overture was agreed by the king and chiefs and was sealed with a gun shut. This actually brought about the socio-economic revolution of Igboland with the emergence of the United African Company. But the perceived increase in wealth and cordiality that existed among the European agents, the missionaries and the people were short lived by the increasing incidence of immorality.

However the high-handedness of the Europeans, which in a way aggravated a serious crisis was the flogging of two young girls resulting in the death of one of the girls earlier taken as a slave by the European agents without any good reason. The move made by the people to show their grievance by beating up the culprits resulted in the bombardment and destruction of towns and villages in Onitsha on 28 October, 1879 by the British army. But following the second attack on the people by David Mclntosh the agent general of the United Africa Company in 1880, Okeke (2006) posits that:

The combination of distrust and disgust led Onitsha elders into serious plans to eliminate what they considered as a threat to their independent life. The aristocrats in the town formed a standard army to attack the factories and the homes of the foreigners. (p. 161).

To Okeke, the supposed attack of the Onitsha on the houses and factories of the foreigners prompted the bombardment of the Igbo people in $28^{\text {th }}$ and $30^{\text {th }}$ of October, 1879 . But there are some school of thoughts that believes that McIntosh's punitive action was not entirely motivated by a desire to redress acts of violence which he alleged had been committed against British property by the Africans. On the contrary, there were other recondite reasons as pointed out in Ekechi (1972) that the fact of the matter was that McIntosh was intent on monopolizing the entire Onitsha trade to the exclusion of all his rivals. In 1879 a French firm had succeeded in obtaining a trading agreement with the chiefs of Onitsha. Mclntosh tried to persuade the chiefs to repudiate this trade agreement with the French. Because of traditional Igbo acceptance of completion as a way of life, the chiefs refused to give the United African Company pre-emptive right 
over the whole trade in the area. Besides, they considered that it would be ungrateful to turn the Frenchmen out of the town after a trade treaty had been signed.

As a matter of fact the chiefs were prepared to trade with Mclntosh and any other merchant who was not an enemy. But they strongly rejected Mclntosh's idea that the whole Igbo territory should become the queen of England's sphere of influence. Being unable to achieve his goal by persuasion, Mclntosh resorted to a might is right policy. To this end, the military action against Onitsha was, therefore an act of desperation resulting from unfulfilled ambition. The seemingly evidence of cohesion in the entire saga can be seen in Okeke's (2006) statement that "for the converts, the bombardment temporarily brought to an end the constant harassment from their non-Christian kinsmen. It was a great relief from persecution. Yet this did not produce any notable response to Christianity" (p.162).

\subsubsection{Cohesion in the mission house}

While giving a conceptual meaning of the word cohesion, Quirk (2001) analytically explain it that if there is cohesion among a group of people, a set of ideas and so on, all the parts or members of it are connected or related in a responsible way to form a whole. More so it is the act or state of cohering, uniting, or sticking together. History has it that the idea behind the formation of mission houses, communities or villages by the missionaries was to gather the converts and separate them from the life of the old. Just as observed by some church historians such as Ajayi (1965) that some of the children housed in the mission houses were as a result of "pawn". Their parents may have collected or borrowed from the mission and used as a kind of collateral or pawn. They were used to assist in the instruction of other children, as interpreters, they also served in the altar and sing the sacred hymns. To this end we are to observe as earlier mentioned that among the aims of the mission house was to keep the children or the converts away from what the missionaries called paganism so as for them to live a good life that is well regulated by the church. And for the good of the church or the mission too, some of these good things or cohesion as witnessed in the mission houses were as follow:

\subsubsection{Language and translation of the Bible}

As earlier noted the converts helped in breaking the language barrier between the missionaries and the Africans in the sense that they were used as interpreters to other coming converts in the house. More so, with the quest of the missionaries to bring the gospel nearer to the people with the need to translate the Bible to the language and understanding of the people really started from the mission houses. The mission houses did a lot to aid the missionaries in the translation of the Bible to the local languages of the people.

\subsubsection{Health}

It is equally of note that the missionaries' intention towards health related matters really started from the mission houses. The determination of the missionaries to tackle the issue of sickness and diseases that were prevalent in African coast, while on their arrival took it upon themselves to establish hospitals and dispensary units in the Christian villages, from where drugs and medications were administered to those that are supposedly in need of it.

Though the missionaries witnessed shortage of man power or medical personnel to undertake the project even to the hinterland and suburbs of the people. The principle of Henry Venn of equipping young Africans with industrial training and professional skills paid-off. As most of them returned home they became a willing tool in medical field at the mission stations as captured by Ajayi (1965) saying:

Samuel Crowther, junior, did establish a dispensary at Abeokuta when he returned from England in 1852, opening three days a week between 10.00am and 4.00pm. He began with about twenty patients attending but the number soon rose to about 110. Missionaries who visited his dispensary or whom he went to treat said he was a good doctor (pp.160-161).

\subsubsection{Agriculture and Commerce}

Mission stations or Christian villages for the RCM were of a great impact during the missionary era with agriculture and commerce in Africa. The point is that these mission stations or communities promptly served as spring boards for new techniques in the processing of agricultural products were adequately put to use. It became a huge success in the sense that the art promoted commerce and civilization following its financial enrichment of the people with the expansion of the agriculture products.

On a final note, the cohesion in the mission stations or communities in spite of the fact that the life and events may 
defer from mission to mission even from missionary to missionary, but the paramount thing has been the atmosphere of discipline and hard work. Morality was inculcated into the children, which in essence means that the mission station not only had unity, but introduced also a kind of a new life into the lives of the children and the converts.

\section{Methodology}

This research employed the use of primary and secondary sources to obtain data. The primary source involved oral interviews while secondary source entail books, journals, and internet materials. These furnished the researchers with the basic information that was necessary for the comprehension, understanding, and analysis of the relevant issues discussed in this work. The research is also based on the deconstruction theory. In this work, this theory was objectively used to reconstruct the contemporary realities in line with the historic principles and ethics of the conflict and cohesion in mission communities in Africa. Deconstruction theory as used in this work envisaged that perhaps if misunderstanding occurs, it deemed it necessary to apply the George Simmel and Lewis Coser's theory respectively. This is because the foundational cause of the problem lies in the influence of culture and modernism. To Simmel's basic approach can be described as "methodological relationism", while to Lewis Coser (1956), conflict not only generates new norms, new institutions, but it is said to be stimulating directly in the economic and technological realm.

\section{Conclusion}

In conclusion it would be pertinent to say that the crisis that ensured in the mission communities of Africa during the period of the European Christian missionary activities can be suggested to be a conflict of confidence. There is much gain to say the fact that the abstract idea which the European missionaries had concerning Africans helped to muddle up concrete ideas in terms of relationships among the mission communities. The truth of the matter has been that the European missionaries never believed in Africa neither did they took them into confidence to be of any moral or intellectual good both to themselves and others. As a total neglect and disparaging of Africans, Ekechi (1972) observes missionaries utterances such as in Mclntosh thought that the Africans have no particle of sense in their brain to think for themselves" (p.45). These are one among the wrong primordial and confrontational sentiments against African society for their refusal to swallow hook, line and sinker the missionaries' unbecoming attitude of making them perpetual servitude. The fact that mediocre and compromising attitude as exhibited by the European missionaries really undermined the cohesion that ought to have entirely pervaded the mission communities was very factual.

\section{References}

Ajayi, J.F.A. (1965). Christian missions in Nigeria 1841-1891. The making of a new Elite. London: Longmans.

Babalola, E.O. (1988).Christianity in West Africa. An Historical Analysis. Ibadan: BRPC.

Barrett, D. B. (1970). Schism \& renewal in Africa: An analysis of six thousand contemporary religious movements. London: Oxford University Press.

Baur, J. (2005). 2000 years of Christianity in African church history. Nairobi: Paulines Publications Africa.

Coser, L. (1956). The functions of social conflict. New York: The Free Press.

De Gruchy, J. W. (1979). The church struggle in South Africa. London: SPCK.

Ndiokwere, N. (1995). Prophecy and revelation. London: SPCK.

Nmah, P. E. (2010). The rise of independent African Churches, 1890-1930: An ethical-genesis of Nigerian nationalism. Journal of African Research Review, Vol.4 (4) No. 17, $482-493$.

Ekechi, F. K. (1972).Missionary enterprise and rivalry in Igbo land 1857-1974. London: Frank.

Falk, P. (1997). The growth of the church in Africa. Kaduna: Baraka.

Gifford, P. (Ed.) (1993). New dimensions in African Christianity. Ibadan: Sefer.

Hinchliff, P. (1968). The church in South Africa. London: SPCK.

Huddleston, T. (1957). Naught for your comfort. Glasgow: Collins.

Nnaemeka, A. (2007).C.M.S Niger Mission: the Anglican mission in Igboland. Enugu: Rabboni.

Nmah, P. E. (2012).Basic \& Applied Christian Ethics: An African perspective. Onitsha: Gucks.

Nmah, P. E. (2008).Religion and Society in Africa. Enugu: Rabboni.

Okeke, D. C. (2006). People of the book: the Anglican mission in Igboland, volume one. Enugu: Rabboni.

Omoyajowo, A. J. (N.D).Gospel and culture from the perspective of Africa churches founded by foreign missions. Retrieved 20/07/15 from http:www.pctii.org/wcc/akin96.html

Shelley, B.C. (2008). Church history in plain language. New York: Zondervan.

Quirk, L. (2001). Longman dictionary of contemporary Engllish. London: Pearson. 